引用格式: 王雨格, 孟全省, 陈秉谱.产权强度对公益林区林地流转的影响: 基于禀赋效应与安全感知视角 [J]. 资源科学, 2021, 43(1): 161-170. [Wang Y G, Meng Q X, Chen B P. Impact of forest land tenure security on the circulation of ecological forest land: From the perspective of endowment effect and security perception[J]. Resources Science, 2021, 43(1): 161-170.] DOI: 10.18402/ resci.2021.01.13

\title{
产权强度对公益林区林地流转的影响 基于禀赋效应与安全感知视角
}

\section{王雨格 ${ }^{1}$, 孟全省 ${ }^{1}$,陈秉谱 ${ }^{2}$}

(1. 西北农林科技大学经济管理学院, 杨凌 712100; 2. 甘肃农业大学财经学院, 兰州 730070)

\begin{abstract}
摘 要: 本文在构建产权强度与农户禀赋效应、安全感知及农户流转行为逻辑关联的基础上,基于甘肃省集体 林权改革监测追踪调研累计 1497 份微观数据, 探讨了产权强度如何通过农户禀赋效应与安全感知影响林地流转行 为。研究发现: (1)产权强度整体上加大了农户禀赋效应和安全感知。具体而言, 产权强度社会认同维度显著增加 农户禀赋效应与安全感知; 产权主体行使能力维度主要影响农户禀赋效应, 对安全感知影响不明显, 其中排他能力 加剧了农户禀赋效应, 交易处置能力则减弱农户禀赋效应。同时随着时间的增加,农户禀赋效应呈减弱趋势, 安全 感知则无显著变化。(2)产权强度影响下的禀赋效应的加剧容易使农户产生高估林地流转价格等倾向, 阻碍林地流 转的发生。(3)产权强度影响下的安全感知的增加可以提升农户对林地权属关系的稳定感, 促进农户流转行为的发 生。(4)禀赋效应与安全感知相互影响共同作用于农户流转行为, 综合考虑禀赋效应及安全感知后, 总效应正向影 响林地流转行为。鉴于此, 本文提出应把握确权方式的灵活运用、通过健全完善林权流转网络平台等方式降低农 户禀赋效应以及注重提升农户安全感知等建议, 以期促进林地流转, 实现公益林林地生态效益和经济效益的最 大化。
\end{abstract}

关键词: 产权强度; 禀赋效应; 安全感知;林地流转; 双变量Probit模型;处理效应模型;甘肃省

DOI :10.18402/resci.2021.01.13

\section{1 引言}

目前中国农业经营以超小规模农户为主要经 营主体,户均承包面积远低于世界银行对小农户 $\left(2 \mathrm{hm}^{2}\right)$ 的定义标准 ${ }^{[1]}$,这种经营模式与现代化农业 的发展不相匹配, 甚至是现代农业建设的瓶颈和根 源问题。为解决这一问题, 政府出台了如健全土 地承包经营权登记制度等政策来促进土地流转的 发展 ${ }^{[2]}$, 以期促进农(林)业适度规模经营。2007年 年底一 2018 年年底, 中国土地流转面积由 426.67 万 $\mathrm{hm}^{2}$ 增加到 3313.33 万 $\mathrm{hm}^{2}$, 年均增长率达 $20.48 \%$ 。 现有研究表明,通过土地流转适度规模经营有利于 实现规模经济, 进而降低平均生产成本, 提高技术
效率 ${ }^{[3-6]}$ 。

学者们针对产权与土地流转之间的关系进行 了研究。部分学者肯定了产权对土地流转的推动 作用 ${ }^{[7]}$,认为权利的明晰可以提升农户安全感知, 降 低土地流转交易成本, 促进规模经营 ${ }^{[8]}$,并且产权安 全感知可以促进农户流转行为发生 ${ }^{[9]}$ 。但是也有学 者得出了相反的结论, 认为产权强度会带来农户禀 赋效应的增加, 抑制农户的流转行为 ${ }^{[10-12]}$, 并且土 地确权并不会明显提高农地市场的活跃程度 ${ }^{[13,14]}$, 对流转影响甚微。对于林权, 学术界也展开了不少 研究,但是主要集中在林权对于农户投资和可持续 管理的影响研究上 ${ }^{[15-19]}$ 。如 Liu 等 ${ }^{[16]}$ 认为林地使用权

收稿日期: 2019-12-17,修订日期: 2020-12-17

基金项目:国家林业局林业软科学研究项目(2018-R08)。

作者简介:王雨格,女,山西临汾人,博士生,研究方向为农业经济管理。E-mail: wangyuge@nwafu.edu.cn

通讯作者:孟全省, 男, 陕西武功人, 教授, 博士生导师, 研究方向为农林经济管理。E-mail: 929880131@qq.com 
和财政激励是森林资源可持续管理的重要政策问 题, Molly 等 ${ }^{[17]}$ 认为产权的建立可减少森林砍伐, Yi 等 ${ }^{[18]}$ 发现农户对林地承包经营权的认知影响了农村 家庭对林业的投资, Qin 等 ${ }^{[19]}$ 的研究表明农户倾向 减少对产权水平低的林地的投资。而关于林地流 转的研究则多集中在流转动因及其决策机理方面, 认为影响农户流转动因及决策的因素有农户分化、 土地细碎化及农户自身禀赋特征等 ${ }^{[20-23]}$ 。仅有少数 学者从产权认知与行为能力角度研究林地流转行 为 ${ }^{[24]}$, 评价集体林地确权对林地流转的政策效果 ${ }^{[25]}$ 。

可以看出, 将产权强度与林地流转纳人同一分 析框架进行研究的较少, 关于产权强度与林地流转 关系的研究仍存在讨论空间, 并且对于林地产权强 度或流转的研究多采用截面数据, 不利于反映其时 间变动趋势, 同时对以公益林为主的林区研究存在 不足。公益林区林地流转的发展是必要的, 由于其 林地的公益林性质, 使得林地在农户手中经济效 益、生态效益都很难得到有效提升, 流转集中到林 业企业、林业大户或其他经营能手的手中才能产生 更高的综合效益。林改以来, 随着时间的推移, 集 体林地的流转规模呈总体稳步上升的状态 (集体林 权改革监测报告 2017), 这一上升趋势是否与产权 强度的增加相关? 产权强度是否确实会带来农户 禀赋效应及安全感知的改变? 这一改变最终又会 如何影响农户流转行为? 这些问题仍有待研究。

鉴于此, 本文选择集体林地以公益林为主的甘 肃省作为研究区, 运用集体林权改革监测 20152017 年累计 1497 份甘肃省农户追踪调研数据, 试图 将产权强度、禀赋效应与安全感知延伸到林地流转 领域, 从林权产权强度出发, 分析产权强度、禀赋效 应、安全感知及农户流转行为之间的作用机理及机 制, 特别是产权强度如何影响农户禀赋效应与安全 感知, 以及眎赋效应与安全感知如何共同作用于农 户林地流转行为, 以期为进一步深化林权制度改 革, 促进林业规模发展提供新的参考。

\section{2 理论分析与研究假设}

\section{1 产权强度对禀赋效应及安全感知的影响分析}

产权强度最早是由罗必良在分析产权强度与 农地流转之间关联性时提出来的, 它是政府代理下 的国家赋权、社会认同与产权主体行使能力的函 数。目前中国土地制度正在发生两个重要转变, 一
是通过确权颁证及延长承包期等方式提升农民土 地产权强度; 二是在三权分置基础上, 鼓励土地经 营权的流转与集中, 以期改善超小规模生产方式, 推进农业经营方式转型 ${ }^{[3]}$ 。这同样适用于林业生 产, 林业经营呈现分散态势, 农户之所以不愿意流 转林地的原因中很重要的一点是担心流转后林地 权益得不到有效保护，会发生诸如权属不清等一系 列问题。于是产权强度就显得格外重要, 即农户 林地权利是否得到法律首肯, 是否得到其社会关 系的认同以及是否对产权具有行使能力是影响农 户流转行为的重要存在。但是增进产权强度一定 能解决流转交易问题吗? 已有研究未得到一致性 结论 ${ }^{[26]}$ 。产权强度的变化一方面会带来农户禀赋 效应的变化 ${ }^{[12]}$, 另一方面又会引起农户安全感知的 波动 ${ }^{[27]}$, 进而对农户流转行为造成不同的影响。

行为经济学家将农民对土地存在价值高估的 现象称为禀赋效应。即对于土地,农户作为买方 (流人方) 愿意支付的价格 (Willing to Pay, WTP) 比 农户作为卖方 (流出方) 愿意出售的价格 (Willing to Accept, WTA) 相比更低 ${ }^{[28]}$ 。有观点认为, 如果一个 人对于其所拥有的物品具有在位控制诉求, 特别是 对该物品有生存依赖性时,该物品的禀赋效应尤为 强烈。中国土地对农户有着不可替代的保障作用 和心理价值 ${ }^{[29]}$, 农户的土地情结较重。所以当产权 强度增加时, 即当土地的集体所有及承包经营权赋 予农户土地使用的权利增强时，或者当土地产权社 会认同程度较高,亦或当农户产权行使能力较高 时, 容易使农户存在价值高估现象, 即增强农户的 禀赋效应, 最终影响农户的行为决策。

农民土地安全感知是指农户对于未来土地权 益遭受损害或者可能失去土地的主观感受 ${ }^{[27]}$, 而这 一主观感受是构建农户行为决策的心理基础。法 律上赋予农户的土地持有权利显著影响农民的土 地产权安全感知,但是产权安全并非完全建立在法 律赋权的基础上 ${ }^{[30]}$, 法律上的确权并不能完全带来 农户心理上的产权安全。农户对产权安全的认知 不仅受到现有信息的影响,也受到其过去经历的影 响,甚至受到农户个人特质、家庭收人结构、土地利 用状况等的影响。林改政策在实施时存在变动性, 产权边界存在模糊性, 因而只有综合考虑法律维 度、社会认同维度以及农户自身行使能力维度基础 
之上产权强度的增加, 才会使农户安全感知得到提 升, 并最终影响农户的决策和行动 ${ }^{[30-32]}$ 。基于以上 分析, 文章提出:

假设 1 : 产权强度会带来禀赋效应和安全感知 的增加。

\section{2 产权强度对林地流转行为的影响分析}

产权强度的增加强化了土地人格化财产属性, 从而会产生较高的禀赋效应, 进而导致农民过高评 估土地价值, 最终抑制土地流转 ${ }^{[29]}$ 。与此同时,农户 产权强度增加的直接结果是农户林地流转时面临 的不确定性的降低, 根据经典的交易成本理论, 土 地产权强度增强会降低不确定性, 减少交易成本, 从而促进土地流转协议的达成, 这种机制可以视作 产权强度带来安全感知效应。如果产权强度带来 禀赋效应的增加, 那么安全感知效应必会存在 ${ }^{[8]}$, 农 户流转行为取决于两种效应的对比, 仅考虑禀赋效 应的抑制作用而忽略安全感知效应的促进作用可 能并不客观。如果禀赋效应是农户普遍心理不可 消除,安全感知效应可能会减弱禀赋效应的影响。 相比禀赋效应,农户对于林地存在更高的安全感知 效应, 因而二者共同作用于林地流转行为时, 可能 最终产生正向影响。如图 1 所示, $L_{n}$ 表示林地流转 行为的无差异曲线 $\left(L_{1}>L_{2}>L_{0}\right), A$ 点、 $B$ 点与 $C$ 点分别 为 $L_{0} 、 L_{1}$ 及 $L_{2}$ 上的点, 代表林地流转行为。 $Q_{n}^{\prime}$ 表示 农户禀赋效应 $\left(Q_{1}^{\prime}>Q_{0}^{\prime}\right), Q_{n}$ 表示农户安全感知 $\left(Q_{1}>\right.$

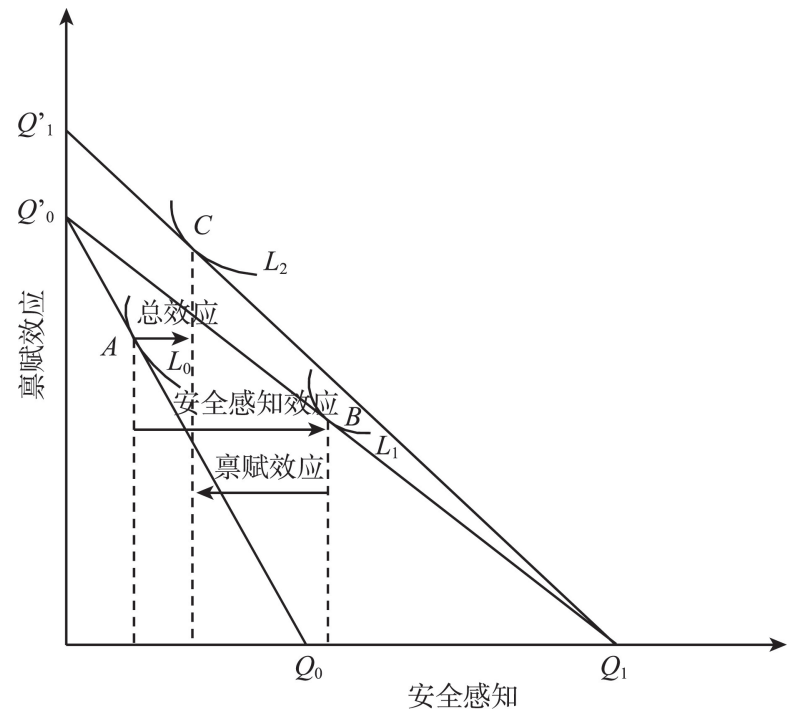

图 1 禀赋效应、安全感知与林地流转行为关系图

Figure 1 Relationship between endowment effect, security perception and forest land circulation behavior
$\left.Q_{0}\right)$ 。农户初始流转行为点为 $A$ 点, 产权强度增进之 后, 带来安全感知由 $Q_{0}$ 到 $Q_{1}$ 的增加, 农户流转行为 由 $A$ 增加到 $B$, 但是产权强度同时带来禀赋效应由 $Q_{0}^{\prime}$ 到 $Q_{1}^{\prime}$ 的增加, 经过安全感知效应与禀赋效应的 双重作用之后, 最终流转行为点为 $C$ 点, 整体而言产 权强度增进带来的总效应是 $A$ 到 $C$ 点的变动效应, 使农户流转行为得到提升。鉴于此,本文提出：

假设 2 : 禀赋效应会负向影响农户流转行为,安 全感知会正向影响林地流转,二者总效应正向影响 农户流转行为。

\section{3 数据来源、研究方法与变量选择}

\section{1 数据来源和处理}

本文数据依托于 2015-2017年国家林业局《集 体林权制度改革监测》项目的调查 (甘肃部分), 该 项目是第一个通过连续跟踪监测林改对象,对集体 林权制度改革成效进行评价的项目，监测内容涉及 到集体林地产权明晰进展情况、深化改革健全服务 跟进状况以及农民对改革的评价和政策需求等多 个方面。运用分层抽样原则, 在 10 个监测县中抽取 5 个样本乡镇 (表 1), 再随机抽取一个样本村, 每村 随机选取 10 个农户,共 500 个样本农户。调查以一 对一访谈为主, 座谈形式为辅, 为提高调研质量, 每 天调研结束后, 调查员互相复合查缺补漏, 及时进 行电话回访。本次选用的数据皆取得 $100 \%$ 有效问 卷, 为了更好体现同一农户的历年变化情况, 删除 1 户换户农户,删除问卷 3 份, 共获得问卷 1497 份。

\section{2 研究方法}

针对假设,本文选取双变量 Probit模型与处理 效应模型进行分析,具体如下：

\subsection{1 双变量Probit模型}

针对假设 1 ,需要检验产权强度对农户禀赋效 应以及对农户安全感知的影响, 首先需检验农户禀 赋效应和安全感知之间是否相关, 通过对禀赋效应 和安全感知的 Pearson 系数检验可知, 二者在 $1 \%$ 的 水平 (双侧)上显著相关,故此处选择使用双变量 Probit模型。具体模型构建如下：

$$
\left\{\begin{array}{l}
y_{1}^{*}=\beta_{11} x_{1 i}^{*}+\beta_{12} z_{1 i}^{*}+\varepsilon_{1} \\
y_{2}^{*}=\beta_{21} x_{2 i}^{*}+\beta_{22} z_{2 i}^{*}+\varepsilon_{2}
\end{array}\right.
$$

式中: $y_{1}^{*}$ 与 $y_{2}^{*}$ 为不可观测的潜变量 $; x_{1 i}^{*}$ 与 $z_{1 i}^{*}$ 表示 可能影响禀赋效应的产权强度与其他解释变量 (包 
表 1 研究区农户样本分布

Table 1 Sample distribution in the study area

\begin{tabular}{|c|c|c|c|c|c|}
\hline 监测县 & 样本乡镇 & 样本数/户 & 监测县 & 样本乡镇 & 样本数/户 \\
\hline \multirow[t]{5}{*}{ 灵台 } & 百里 & 30 & 泾川 & 党原 & 30 \\
\hline & 朝那 & 30 & & 飞云 & 30 \\
\hline & 独店 & 30 & & 丰台 & 30 \\
\hline & 什字 & 30 & & 高坪 & 30 \\
\hline & 中台 & 30 & & 玉都 & 30 \\
\hline \multirow[t]{5}{*}{ 康县 } & 城关 & 30 & 合水 & 板桥 & 30 \\
\hline & 碾坝 & 30 & & 店子 & 30 \\
\hline & 太石 & 30 & & 段家集 & 30 \\
\hline & 铜钱 & 30 & & 固城 & 30 \\
\hline & 阳坝 & 30 & & 吉砚 & 30 \\
\hline \multirow[t]{5}{*}{ 通渭 } & 第三铺 & 30 & 宕昌 & 阿坞 & 30 \\
\hline & 新景 & 27 & & 官亭 & 30 \\
\hline & 鸡川 & 30 & & 哈达铺 & 30 \\
\hline & 什川 & 30 & & 何家堡 & 30 \\
\hline & 李家店 & 30 & & 南河 & 30 \\
\hline \multirow[t]{5}{*}{ 徽县 } & 永宁 & 30 & 会宁 & 汉家岔 & 30 \\
\hline & 榆树 & 30 & & 侯家川 & 30 \\
\hline & 银杏 & 30 & & 会师镇 & 30 \\
\hline & 嘉陵 & 30 & & 平头川 & 30 \\
\hline & 高桥 & 30 & & 头寨子 & 30 \\
\hline \multirow[t]{5}{*}{ 清水 } & 白沙 & 30 & 永靖 & 关山 & 30 \\
\hline & 草川铺 & 30 & & 岘塬 & 30 \\
\hline & 陇东 & 30 & & 小岭 & 30 \\
\hline & 永清 & 30 & & 徐顶 & 30 \\
\hline & 新城 & 30 & & 杨塔 & 30 \\
\hline 合计 & & & 1497 & & \\
\hline
\end{tabular}

括户主特征、家庭特征与土地特征等, 下同), $\beta_{11}$ 与 $\beta_{12}$ 为其待估系数; $x_{2 i}^{*}$ 与 $z_{2 i}^{*}$ 表示可能影响安全感 知的产权强度与其他解释变量, $\beta_{21}$ 与 $\beta_{22}$ 为其待估系 数; $\varepsilon_{1}$ 与 $\varepsilon_{2}$ 为扰动项, 服从二维联合正态分布。可观 测变量 $y_{1}$ 和 $y_{2}$ 由以下方程决定:

$$
\begin{aligned}
& y_{1}= \begin{cases}1, & y_{1}^{*}>0 \\
0, & y_{1}^{*} \leqslant 0\end{cases} \\
& y_{2}= \begin{cases}1, & y_{2}^{*}>0 \\
0, & y_{2}^{*} \leqslant 0\end{cases}
\end{aligned}
$$

式中: $y_{1}$ 表示农户是否存在禀赋效应; $y_{2}$ 表示农户是 否具有安全感知。

\subsection{2 处理效应模型}

针对假设 2 , 由于林权制度改革后所有农户的 产权强度都比林权改革前有所增加, 而本文希望评
估农户的流转行为是否会比其产权强度未增强时 (假想)更多,因此选用处理效应模型。参照 Madda$\mathrm{la}^{[33]}$ 的观点,构建处理效应模型如下:

$$
y_{i}=\beta x_{i}^{\prime}+\gamma D_{i}+\varepsilon_{i}
$$

式中: $y_{i}$ 表示个体 $i$ 的林地流转情况; $x_{i}^{\prime}$ 表示影响林 地流转的户主特征、家庭特征与土地特征等变量, $\beta$ 为其待估系数; $D_{i}$ 表示禀赋效应、安全感知等处理变 量, $\gamma$ 为其待估系数; $\varepsilon_{i}$ 为方程扰动项。其中, 处理变 量 $D_{i}$ 由以下方程所决定：

$$
D_{i}=1\left(\delta Z_{i}^{\prime}+\mu_{i}\right)
$$

式中: $1\left(^{*}\right)$ 为示性函数; $Z_{i}^{\prime}$ 为影响处理变量的产权 强度以及户主特征、家庭特征与土地特征等变量, $\delta$ 为其待估系数; $\mu_{i}$ 为方程扰动项。

\section{3 变量选择与统计描述}

被解释变量: 本文的被解释变量为林地是否 流转。

处理变量: 主要包括禀赋效应和安全感知效 应。若农户过高估计林地流转价格,则视作存在禀 赋效应, 反之则不存在。若农户不担心会丧失二轮 承包资格或认为日后仍可回乡务农,则说明农户认 为林地未来调整的可能性小, 视为农户具有安全感 知, 反之则不具有。

解释变量: 主要解释变量为产权强度, 产权强 度是法律赋权、社会认同及产权主体行使能力的函 数。由于集体林地确权颁证工作已基本完成,产权 强度法律层面达到统一, 因此本文主要以社会认同 和产权主体行使能力为表征。为了更好地经营发 展,林权证的发放方式存在农户保管和村小组保管 的差别,而当林权证在农户自己手中时,该权利更 容易得到农户社会关系的认可,故用林权证是否发 放在农户手中作为社会认同的表现方式。产权主 体行使能力主要表现在交易处置能力与排他能力 上,交易和处置能力表现在跟林地流转相关联的流 转信息是否容易获得, 排他能力的现实表征即是否 发生过林地纠纷。其他解释变量包括户主特征变 量、家庭特征变量及土地特征变量如表 2 所示。

可以看出,整体来看,农户对林地的禀赋效应 均值为 0.59 , 对林地的安全感知均值达 0.657 , 二者 标准差较小, 均值较稳定, 离散程度小。其中农户 禀赋效应较小的原因一方面可能因为公益林林地 经济价值较小,不能提供非常高水平的保障价值, 
表 2 变量选择、定义及描述性统计

Table 2 Variable selection, definition, and descriptive statistics

\begin{tabular}{|c|c|c|c|c|}
\hline 类型 & 变量 & 定义 & 均值 & 标准差 \\
\hline 主要被解释变量 & 林地是否流转 & $1=$ 流转, $0=$ 不流转 & 0.091 & 0.007 \\
\hline \multirow[t]{3}{*}{ 处理变量 } & 禀赋效应 & $1=$ 存在禀赋效应, $0=$ 不存在禀赋效应 & 0.590 & 0.013 \\
\hline & 安全感知 & $1=$ 存在安全感知, $0=$ 不存在安全感知 & 0.657 & 0.012 \\
\hline & 综合效应 & $\begin{array}{l}1=\text { 存在禀赋效应或安全感知, } 0=\text { 不存在 } \\
\text { 禀赋效应和安全感知 }\end{array}$ & 0.809 & 0.010 \\
\hline \multirow[t]{3}{*}{ 主要解释变量 } & 产权强度社会认同维度 & $\begin{array}{l}1=\text { 林权证在农户手中, } 0=\text { 林权证未在农 } \\
\text { 户手中 }\end{array}$ & 0.832 & 0.012 \\
\hline & $\begin{array}{l}\text { 产权强度产权主体行使能力 } 1 \\
\text { (交易处置能力) }\end{array}$ & $\begin{array}{l}\text { 流转信息获取情况 }(1=\text { 很难获取, } 2=\text { 难 } \\
\text { 获取, } 3=\text { 一般, } 4=\text { 容易获取, } 5=\text { 非常容 } \\
\text { 易获取 })\end{array}$ & 1.737 & 0.028 \\
\hline & $\begin{array}{l}\text { 产权强度产权主体行使能力 } 2 \\
\text { (排他能力) }\end{array}$ & $\begin{array}{l}\text { 林权纠纷状况 (1=未发生过林地纠纷, } \\
0=\text { 发生过林地纠纷) }\end{array}$ & 0.982 & 0.004 \\
\hline \multirow[t]{8}{*}{ 其他解释变量 } & 户主年龄 & 岁 & 53.815 & 0.270 \\
\hline & 户主性别 & $1=$ 男, $0=$ 女 & 0.952 & 0.006 \\
\hline & 户主受教育程度 & $1=$ 小学及以下, $2=$ 初中, $3=$ 高中及以上 & 1.689 & 0.020 \\
\hline & 家庭人口数量 & 人 & 4.600 & 0.044 \\
\hline & 家庭劳动力数量 & 人 & 2.548 & 0.032 \\
\hline & 劳动力占家庭人口比 & $\%$ & 0.571 & 0.007 \\
\hline & 家中是否有人担任村干部 & $1=$ 是, $0=$ 否 & 0.170 & 0.010 \\
\hline & 林地面积 & 亩 & 35.187 & 1.714 \\
\hline
\end{tabular}

另一方面农户对于林地的依存度较低, 对林地的情 感依赖水平不高 ${ }^{[34]}$ 。而农户安全感知较高的原因很 可能是林地社会认同度较高, 林权证在农户手中的 均值高达 0.832 , 且稳定性较高, 并且在新一轮林改 确权后林地几乎未进行过大幅调整,这大大增强了 农户的安全感知。

\section{4 结果与分析}

\section{1 产权强度对农户禀赋效应及安全感知影响 分析}

如表 3 所示, 产权强度中社会认同维度对农户 禀赋效应和安全感知都有正向作用,并且社会认同 对安全感知的增加程度要大于对禀赋效应的增加 程度。产权强度产权主体行使能力维度中的交易 处置能力对禀赋效应有显著负影响, 即随着交易处 置能力越强, 流转信息越容易获得, 农户禀赋效应 越低。这是因为随着流转信息获取成本越低,农户 对流转现状、交易信息获取越全面,进而调整不合 实际的过高的价格期望, 禀赋效应得到缓解。但是 交易处置能力对禀赋效应的抑制作用不如社会认 同带来的提升效果明显, 并且产权强度行使能力维 度中的排他能力亦会加剧农户禀赋效应, 即当农户
排他能力越强时, 林权纠纷等状况越少, 越容易使 农户增加对林地价值的预期, 故产权强度对农户禀 赋效应整体呈增加效应。产权强度行使能力对农 户安全感知并没有显著影响,这很可能与农户安全 感知整体水平较高有关。综合而言产权强度会增 强农户禀赋效应和安全感知, 假设 1 得以验证。

同时, 随着时间的增加,农户禀赋效应呈减弱 趋势, 说明农户禀赋效应是一个不断变化的动态过 程。其可能的原因在于随着时间的增加,农户对林 地流转状况日渐有了一个较为稳定的认知, 能够将 流转价格期望调整到一个合适的水平,降低禀赋效 应。而安全感知随着时间推移变化不显著,这可能 与农户初始安全感知较高有关。此外,显著影响禀 赋效应的还有户主年龄, 户主年龄越大, 其对土地 的保证需求等其他附加需求越高, 因而对土地的附 加价值估计更高, 有更强的禀赋效应。显著影响安 全感知的有家庭劳动力数量, 劳动力数量越高, 农 户安全感知越高。

\section{2 禀赋效应及安全感知对农户流转行为的影响 分析}

如表 4 所示, 处理效应模型可以同时处理综合 


\section{表 3 产权强度对禀赋效应及安全感知的影响}

Table 3 Impact of tenure security on endowment effect and security perception

\begin{tabular}{|c|c|c|}
\hline & 禀赋效应 & 安全感知 \\
\hline 产权强度社会认同维度 & $1.063(0.092) * * *$ & $1.655(0.100) * * *$ \\
\hline 产权强度产权主体行使能力 1 (交易处置能力) & $-0.109(0 . .038) * * *$ & $0.007(0.040)$ \\
\hline 产权强度产权主体行使能力 2(排他能力) & $0.513(0.265) *$ & $-0.301(0.275)$ \\
\hline 户主年龄 & $0.008(0.003) * *$ & $0.000(0.004)$ \\
\hline 户主性别 & $0.053(0.164)$ & $0.124(0.173)$ \\
\hline 户主受教育程度 & $0.022(0.046)$ & $-0.032(0.048)$ \\
\hline 林地面积 & $-0.001(0.001)$ & $-0.000(0.001)$ \\
\hline 家庭人口数量 & $0.002(0.025)$ & $0.004(0.037)$ \\
\hline 家庭劳动力数量 & $-0.008(0.035)$ & $0.075(0.036) * *$ \\
\hline 年份 & $-0.130(0.050) * * *$ & $0.010(0.053)$ \\
\hline Prob $>c h i^{2}$ & & \\
\hline
\end{tabular}

注: ***、**、*分别表示在 $1 \%, 5 \%$ 以及 $10 \%$ 的水平上显著, 括号内为标准误, 并且模型通过了沃尔德检验,说明选用双变量P Probit模型是合 适的。

效应 (禀赋效应及安全感知) 对林地流转的影响与 影响综合效应的变量。表中第 2 列为影响农户流转 行为的计量结果, 第 3 列反映可能影响农户综合效 应的计量结果。其结果说明产权强度虽会加剧农 户禀赋效应进而负向影响林地流转,但同时也会通 过提升农户安全感知正向促进流转行为。即产权
强度尽管会使农户赋予林地过高的心理价值(禀赋 效应), 在行为决策时容易偏离林地真实价值, 倾向 于不进行林地流转; 但同时也会提升农户的安全感 知, 降低农户对权属关系的不确定感,使其越放心 将林地进行流转。综合考虑农户禀赋效应和安全 感知之后, 林地产权强度正向影响农户林地流转行

表4 禀赋效应、安全感知及综合效应对林地流转的影响与产权强度对综合效应的影响

Table 4 Effects of endowment effect and security perception on forest land circulation and property right security on comprehensive effect

\begin{tabular}{lcc}
\hline & 林地流转 & 综合效应 \\
\hline 综合效应 & $0.135(0.040) * * *$ & - \\
禀赋效应×产权强度 & $-0.142(0.013) * * *$ & - \\
安全感知×产权强度 & $0.082(0.014) * * *$ & - \\
产权强度社会认同维度 & - & $1.702(0.100)^{* * *}$ \\
产权强度产权主体行使能力 1(交易处置能力) & - & $0.009(0.048)$ \\
产权强度产权主体行使能力2(排他能力) & - & $-0.054(0.297)$ \\
户主性别 & $-0.014(0.033)$ & $0.024(0.057)$ \\
户主年龄 & $-0.002(0.001) * *$ & $0.009(0.004)^{* *}$ \\
户主受教育程度 & $-0.008(0.009)$ & $0.024(0.057)$ \\
林地面积 & $0.001(0.000) * * *$ & $-0.000(0.001)$ \\
家庭人口数量 & $-0.001(0.005)$ & $0.019(0.026)$ \\
家中是否有人担任村干部 & $0.028(0.019)$ & - \\
家庭劳动力数量 & $0.013(0.007) *$ & - \\
劳动力占家庭人口比 & - & $0.033(0.062)$ \\
年份 & - & $-0.162(0.062)$ \\
Cons & - & $326.636(125.301)$ \\
\hline
\end{tabular}

注: 在设立模型之前, 文章已对所选变量进行共线性检验, 结果显示各解释变量之间不存在高度多重共线,同时, 文章经过增减变量反复 进行回归,重要变量的影响方向基本一致。 
转信息时,对林地流转的了解程度和对流转状况的

为。其原因很可能在于一方面公益林区的林地并 不是农户生存依赖的主要对象, 其经济价值限制了 农户禀赋效应的作用结果, 另一方面林权流转仅是 经营权的暂时流转, 不会造成流转后无法按时收回 林地的损失, 极大增强农户安全感知。同时公益林 的流转并不会改变林地用途, 故不会带来地力折损 的损失, 这种交易损失的减轻也会使得农户禀赋效 应的作用效果得到一定程度的减轻。所以总体来 看, 产权强度对林地流转存在显著促进作用。

此外, 影响农户流转行为的有户主年龄、林地 面积以及家庭劳动力数量。户主年纪越大越不愿 意流转林地, 这与实际情况相符, 农户年纪越大对 土地的依赖越强, 越倾向于不流转林地; 林地面积 正向影响农户流转行为, 这可能是因为农户林地面 积越大, 带来的流转收人相比自己经营更多, 因而 更愿意流转林地; 而家庭劳动力数量越多, 农户对 林地的安全感知越高, 越容易促进其林地流转。

\section{3 稳健性检验}

首先, 表 4 中影响综合效应的因素在一定程度 上验证表 3 结果的稳健性, 即产权强度社会认同维 度对禀赋效应及安全感知的影响方向与表 3 估计一 致。其次, 为验证表 4 结果的稳健性, 本文选用面板 Logitic 模型进行稳健性检验, 直接验证产权强度对 林地流转的影响。具体结果如表 5 所示。

检验结果显示, 主要变量对林地流转的影响跟 表 4 中估计的一致。即产权强度中的社会认同维度 对林地流转整体呈促进作用, 当农户的权利越受到 其社会关系认同时, 越能减少产权交易过程中的监 督成本及逆向选择等交易成本，增进其流转行为。 产权强度产权主体行使能力中的交易处置能力亦 会促进林地流转行为, 即当农户越容易获取林地流

表 5 产权强度对流转行为的影响

Table 5 Impact of tenure security on forest land circulation

\begin{tabular}{lc}
\hline & 系数 (标准误差) \\
\hline 产权强度社会认同维度 & $0.445(0.253) *$ \\
产权强度产权主体行使能力 1(交易处置能力) & $0.336(0.122) * * *$ \\
产权强度产权主体行使能力 2(排他能力) & $-1.134(0.528) * *$ \\
禀赋效应×产权强度 & $-3.081(0.389)^{* * *}$ \\
安全感知 $\times$ 产权强度 & $2.990(0.525)^{* * *}$ \\
控制变量 & 已引人 \\
cons & $-1.232(0.967)$ \\
Prob $>C h i^{2}$ & 0.0000 \\
\hline
\end{tabular}

把控能力越强, 越能降低禀赋效应, 倾向于流转林 地。而产权强度产权主体行使能力中排他能力较 强的农户禀赋效应也较强, 因而会阻碍林地流转的 发生。同时表 5 还验证了产权强度通过禀赋效应负 向影响农户流转行为, 通过安全感知效应正向影响 农户流转行为, 可见表 4 所得结果具有稳健性。假 设 2 得以验证。

\section{5 结论与建议}

\section{1 结论}

本文基于 2015-2017年甘肃省集体林权制度 改革监测的面板数据, 将产权强度、禀赋效应与安 全感知延伸到林地流转领域, 运用双变量 Probit模 型与处理效应模型分析产权强度与农户禀赋效应、 安全感知及林地流转之间的关系, 重点讨论了产权 强度对农户禀赋效应与安全感知的影响, 以及禀赋 效应与安全感知如何相互影响共同作用于林地流 转。通过实证分析及稳健性检验, 得出如下结论:

（1）产权强度整体上会带来农户禀赋效应以及 安全感知的增加。其中, 产权强度社会认同维度显 著增加农户禀赋效应与安全感知, 即当农户的林地 权属关系得到其社会关系的认同时,一方面容易导 致农户过高评估土地价值, 加大禀赋效应, 另一方 面也会降低农户对流转的不确定性,增进农户安全 感知,并且社会认同对农户安全感知的增加程度大 于对农户禀赋效应的增加程度。而产权强度产权 主体行使能力维度主要影响农户禀赋效应, 对安全 感知的影响不显著。具体而言, 产权主体行使能力 维度中的排他能力加剧农户禀赋效应, 即当农户排 他能力越强时, 林权纠纷等状况越少, 越容易使农 户对林地价值的预期增加, 加剧农户禀赋效应; 而 交易处置能力则可以有效减弱农户禀赋效应, 即当 农户对流转信息获取越及时越全面时,越能积极调 整对林地流转价格的预期,缓解禀赋效应。

(2)受产权强度影响的禀赋效应的加剧会负向 影响农户林地流转行为。当农户禀赋效应增加时, 会使农户在评估林地价值时更多考虑其承担的多 功能总体价值, 偏离基于林地利用效率所做的价值 评价, 容易产生对林地流转价格期望过高等心理, 使农户做出不流转的行为决策,最终会负向影响农 
户的林地流转行为, 阻碍流转的发生。

(3) 受产权强度影响的安全感知的增加可以促 进农户流转行为的发生。当农户安全感知增加时, 会降低农户对林地权属关系的不确定感, 使农户更 放心将林地进行流转, 减少由于不确定性带来的交 易成本, 正向影响农户的林地流转行为, 促进流转 协议的达成。

(4) 禀赋效应与安全感知相互影响, 共同作用 于林地流转, 综合考虑禀赋效应及安全感知后, 总 效应会正向影响农户的林地流转行为。农户㐭赋 效应与安全感知显著相关, 二者同时对农户林地流 转行为产生影响, 最终使得总效应正向影响农户林 地流转行为。可以认为, 产权强度虽会加剧农户高 赋效应抑制林地流转但同时也会提升农户安全感 知增进流转行为, 最终使得产权强度显著正向影响 农户林地流转行为的发生。

\section{2 建议}

基于上述研究结论, 本文提出以下几点关于促 进公益林区林地流转的建议: 一是注重确权方式的 灵活运用, 对通过确权发证促进流转市场发育的主 张应保持谨慎态度, 需综合把握产权强度提升带来 的农户禀赋效应与安全感知。二是注重采取措施 降低农户禀赋效应, 如健全完善林地流转网络平 台, 便于农户及时掌握林地流转信息, 减少禀赋效 应的同时降低交易成本, 促进流转行为的发生。三 是提升农户的安全感知, 如进一步细化林地承包经 营等权利, 对林地调整持谨慎态度, 增进农户对林 地权属关系稳定的预期, 以期促进林地流转, 最终 实现公益林地最大化生态效益和经济效益的发展。

本文关于产权强度与禀赋效应及安全感知的 关系与已有研究较为一致 ${ }^{[3,8,11]}$, 关于产权强度与林 地流转关系的结论与部分研究一致 ${ }^{[24]}$ 。前人鲜有将 产权强度、禀赋效应及安全感知纳人同一研究框架 中进而考虑对林地流转影响的。本文在前人的研 究基础上, 对产权强度、禀赋效应、安全感知及农户 林地流转行为进行梳理分析, 并依据研究结论为如 何实施产权促进林地流转提供了一定的理论借 鉴。但是, 本文讨论的公益林林地经济价值较低, 这一条件下产权强度增强农户禀赋效应的同时更 加促进了农户安全感知的提升, 最终会对农户流转 行为产生正向影响, 那么当经济价值较高时, 亭赋
效应的增加程度是否会大幅上升? 安全感知是否 会下降? 变化了的禀赋效应和安全感知又会对农 户流转行为产生怎样的影响? 这些都需要进一步 的研究和讨论,以期为促进多种类型 (如经济林、竹 林等)林地流转,为推进林业要素的配置和培育林 地规模经营的新型经营主体提供新的参考。

\section{参考文献(References):}

[1] 胡新艳, 陈小知, 米运生, 等. 农地整合确权政策对农业规模经 营发展的影响评估: 来自准自然实验的证据[J]. 中国农村经 济, 2018, (12): 83-102. [Hu X Y, Chen X Z, Mi Y S, et al. The impact of agricultural land consolidation and titling policies on the development of agricultural scale management: Evidence from quasi- natural experiments[J]. Chinese Rural Economy, 2018, (12): 83-102.]

[2] Liu Y, Yan B J, Wang Y, et al. Will land transfer always increase technical efficiency in China? A land cost perspective[J]. Land Use Policy, 2019, 82: 414-421.

[3] 罗必良. 科斯定理反思与拓展: 兼论中国农地流转制度改革与 选择[J]. 经济研究, 2017, 52(11): 178-193. [Luo B L. Rethinking and extension of the Coase Theorem: Reform and choice of land circulation Institutions in rural China[J]. Economic Research Journal, 2017, 52(11): 178-193.]

[4] 杨宗耀, 仇焕广, 纪月清. 土地流转背景下农户经营规模与土地 生产率关系再审视: 来自固定粮农和地块的证据[J]. 农业经济 问题, 2020, (4): 37-48. [Yang Z Y, Qiu H G, Ji Y Q. Re-exploration of the inverse productivity: Size relationship using the fixed farmers' fixed plots data in the context of land transfer[J]. Issues in Agricultural Economy, 2020, (4): 37-48.]

[5] 刘汉成, 关江华. 适度规模经营背景下农村土地流转研究[J]. 农 业经济问题, 2019, (8): 59-64. [Liu H C, Guan J H. Study on the problem of farmland transfer on the background of moderate scale management[J]. Issues in Agricultural Economy, 2019, (8): 59-64.]

[6] 张亚丽, 白云丽, 辛良杰. 耕地质量与土地流转行为关系研究 [J]. 资源科学, 2019, 41(6): 1102-1110. [Zhang Y L, Bai Y L, Xin L J. Relationships between cultivated land quality and land transfer behaviors at the plot scale[J]. Resources Science, 2019, 41(6): 1102-1110.]

[ 7 ] Kemper N, Ha L V, Klump R. Property rights and consumption volatility: Evidence from a land reform in Vietnam[J]. World Development, 2015, 71: 107-130.

[8] 王士海, 王秀丽. 农村土地承包经营权确权强化了农户的禀赋 效应吗: 基于山东省 117 个县 (市, 区) 农户的实证研究[J]. 农业 经济问题, 2018, (5): 92-102. [Wang S H, Wang X L. Does the confirmation of rural land contract management right strengthen the endowment effect of farmers: An empirical study based on questionnaire survey of rural households in 117 counties in Shan- 
dong Province[J]. Issues in Agricultural Economy, 2018, (5): 92102.]

[9] 黄培锋, 卢素兰, 黄和亮. 产权安全感知对林地流转的影响研究 [J]. 林业经济问题, 2020, 40(4): 366-373. [Huang P F, Lu S L, Huang H L. A study on the influence of property right security perception on forest land circulation[J]. Issues of Forestry Economics, 2020, 40(4): 366-373.]

[10] 钟文晶, 罗必良. 禀赋效应, 产权强度与农地流转抑制: 基于广 东省的实证分析[J]. 农业经济问题, 2013, (3): 6-16. [Zhong W

J, Luo B L. Endowment effect, property strength and restraint of agricultural land transfer: Farmer household's survey data from Guangdong Province[J]. Issues in Agricultural Economy, 2013, (3): 6-16.]

[11] 仇童伟, 罗必良. 农地产权强度对农业生产要素配置的影响[J]. 中国人口·资源与环境, 2018, 28(1): 63-70. [Qiu T W, Luo B L. The impacts of land tenure intensity on distribution of agricultural factors[J]. China Population, Resources and Environment, 2018, 28 (1): 63-70.]

[12] 罗必良. 从产权界定到产权实施: 中国农地经营制度变革的过 去与未来[J]. 农业经济问题, 2019, (1): 17-31. [Luo B L. The property rights: From delimitation to implementation: The logical clue of Chinese farmland management system transformation[J]. Issues in Agricultural Economy, 2019, (1): 17-31.]

[13] Place F, Migot-Adholla S E. The economic effects of land registration on smallholder farms in Kenya: Evidence from Nyeri and Kakamega districts[J]. Land Economics, 1998, 74(3): 360-373.

[14] Jacoby H, Minten B. Land titles, investment, and agricultural Productivity in Madagascar: A poverty and social impact analysis[J]. World Bank Other Operational Studies, 2006, (4): 1-54.

[15] Wang G Y, Innes J L, Lei J F, et al. China's forestry reforms[J]. Science, 2007, 318(5856): 1556-1557.

[16] Liu C, Liu H, Wang S. Has China's new round of collective forest reforms caused an increase in the use of productive forest inputs? [J]. Land Use Policy, 2017, 64: 492-510.

[17] Lipscomb M, Prabakaran N. Property rights and deforestation: Evidence from the terra legal land reform in the Brazilian Amazon[J]. World Development, 2020, DOI: 10.1016/j.worlddev.2019.104854

[18] Yi Y Y, Köhlin G, Xu J T. Property rights, tenure security and forest investment incentives: Evidence from China's Collective Forest Tenure Reform[J]. Environment and Development Economics, 2014, 19(1): 48-73

[19] Qin P, Xu J T. Forest land rights, tenure types, and farmers' investment incentives in China: An empirical study of Fujian Province[J]. China Agricultural Economic Review, 2013, 5(1): 154170.

[20] 孔凡斌, 廖文梅. 基于收人结构差异化的农户林地流转行为分 析: 以江西省为例[J]. 中国农村经济, 2011, (8): 89-96. [Kong F B, Liao W M. An analysis of farmer households' woodland transferring behavior based on their differential income structure: Tak- ing Jiangxi Province as example[J]. Chinese Rural Economy, 2011, (8): 89-96.]

[21] 肖慧婷, 谢芳婷, 杜鹃, 等. 农户资源禀赋差异性对林地流转行 为影响实证研究: 基于江西集体林区 10 县 503 农户的调查 [J]. 林业经济, 2018, 40(11): 44-51. [Xiao H T, Xie F T, Du J, et al. An empirical research on the impact of the difference in householder resource endowments on forestland circulation behavior: Survey of 503 householders from 10 counties in collective forest regions in Jiangxi[J]. Forestry Economics, 2018, 40(11): 44-51.]

[22] Xie H L, Lu H. Impact of land fragmentation and non-agricultural labor supply on circulation of agricultural land management rights [J]. Land Use Policy, 2017, 68: 355-364.

[23] 张寒, 程娟娟, 刘骤. 基于内生性视角的非农就业对林地流转的 效应评价: 来自9省 1497 户林农的连续监测数据[J]. 农业技术 经济, 2018, (1): 122-131. [Zhang H, Cheng J J, Liu C. The effect of off-farm employment on forestland transfer: An analysis based on endogenous perspective with 1497 households dataset from 9 provinces[J]. Journal of Agrotechnical Economics, 2018, (1): 122131.]

[24] 史若昀, 刘伟平. 基于产权强度理论的林地流转行为研究: 以福 建省 10 县(市) 50 村农户调查为例[J]. 东南学术, 2017, (4): 8693. [Shi R Y, Liu W P. Research on forest land circulation behavior based on the theory of property right intensity: A case study of 50 villages in 10 counties (cities) of Fujian Province[J]. Southeast Academic Research, 2017, (4): 86-93.]

[25] 朱文清, 张莉琴. 集体林地确权到户对林地流转的政策效果分 析[J]. 资源科学, 2018, 40(7): 1407-1417. [Zhu W Q, Zhang L Q.

The impact of confirming collective forest land property rights to households on the forest land circulation behavior of farmers[J]. Resources Science, 2018, 40(7): 1407-1417.]

[26] 罗必良. 农地确权, 交易含义与农业经营方式转型: 科斯定理拓 展与案例研究[J]. 中国农村经济, 2016, (11): 2-16. [Luo B L. Farmland tenure confirm, transaction and transformation of agricultural management mode: Expansion of Coase Theorem and case study[J]. Chinese Rural Economy, 2016, (11): 2-16.]

[27] 马贤磊, 仇童伟, 钱忠好. 土地产权经历, 产权情景对农民产权 安全感知的影响: 基于土地法律执行视角 [J]. 公共管理学报, 2015, 12(4): 111-121. [Ma X L, Qiu T W, Qian Z H. Study about the impact of land tenure experience and tenure environment on farmers' tenure security perception: From the perspective of land laws' implementation[J]. Journal of Public Management, 2015, 12 (4): 111-121.]

[28] Thaler R H. Toward a positive theory of consumer choice[J]. Journal of Economic Behavior \& Organization, 1980, 1(1): 39-60.

[29]朱文玨, 罗必良. 农地流转、禀赋效应及对象歧视性: 基于确权 背景下的 IV-Tobit 模型的实证分析[J]. 农业技术经济, 2019, (5): 4-15. [Zhu W J, Luo B L. The formation of farmland endowment effect and its object discrimination: An empirical analysis based on IV-Tobit model[J]. Journal of Agrotechnical Economics, 
2019, (5): 4-15.]

[30] Broegaard R. Land tenure insecurity and inequality in Nicaragua [J]. Development and Change, 2005, 36(5): 845-864.

[31] Van Gelder J L. Feeling and thinking: quantifying the relationship between perceived tenure security and housing improvement in an informal neighborhood in Buenos Aires[J]. Habitat International, 2007, 31(2): 219-231.

[32] 丰雷, 蒋妍, 叶剑平, 等. 中国农村土地调整制度变迁中的农户 态度: 基于 1999-2010年 17 省份调查的实证分析[J]. 管理世
界, 2013, (7): 44-58. [Feng L, Jiang Y, Ye J P, et al. The attitude of farmers in the institutional change of rural land adjustment in China: An empirical analysis based on the survey of 17 provinces from 1999 to 2010[J]. Management World, 2013, (7): 44-58.]

[33] Maddala G S. Limited-dependent and Qualitative Variables in Econometrics[M]. Cambridge: Cambridge University Press, 1983.

[34] Pierce J L, Kostova T, Dirks K, et al. The state of psychological ownership: Integrating and extending a century of research[J]. Review of General Psychology, 2003, 7(1): 84-107.

\title{
Impact of forest land tenure security on the circulation of ecological forest land: From the perspective of endowment effect and security perception
}

\author{
WANG Yuge ${ }^{1}$, MENG Quanxing ${ }^{1}$, CHEN Bingpu ${ }^{2}$ \\ (1. College of Economics and Management, Northwest A\&F University, Yangling 712100, China; \\ 2. College of Finance and Economics, Gansu Agriculture University, Lanzhou 730070, China)
}

\begin{abstract}
Based on an examination of the logical relationship between forest land tenure security and endowment effect, security perception, and farmers' land transfer behavior, and using survey data of 1497 samples collected by the monitoring program of collective forest rights reform in Gansu Province, this study analyzed the impact of forest land tenure security on households' transfer of forest land through the endowment effect and security perception of farmers. The results show that higher forest land tenure security can improve the endowment effect and security perception of farmers. Specifically, the social identity dimension of property rights significantly increases the endowment effect and security perception of farmers; the exercise ability dimension of property rights mainly affects the endowment effect of farmers, but has no obvious impact on security perception. Ability of exclusion intensifies the endowment effect of farmers, while transaction and disposal ability effectively weakens the endowment effect. Property right security impact on endowment effect is weakened with the increase of time, but perception has no significant change. Endowment effect will hinder the behavior of forest land transfer while security perception could promote transfer they influence each other and affect the circulation behavior at the same time. When endowment effect and security perception are both considered, the total effect has a positive impact on forest land circulation behavior. In view of this, we suggest that the government could pay more attention to the flexible use of confirming the forest land rights and improving the online platform of forest land circulation to reduce the endowment effect of farmers and pay attention to enhance the security perception of farmers, in order to promote the circulation of forest land and realize the development of the maximum ecological and economic benefits of ecological forest land.
\end{abstract}

Key words: forest land tenure security; endowment effect; security perception; forest land circulation; bivariate Probit model; treatment effect model; Gansu Province 